\title{
Ricinus communis extract inhibits the adipocyte differentiation through activating the Wnt/ $\beta$-catenin signaling pathway
}

\author{
Bora Kim ${ }^{1}$, Hyun-Soo Kim ${ }^{2 *}$ \\ ${ }^{1}$ Division of Biomedicinal Chemistry and Cosmetics, Mokwon University, Daejeon 35349, Korea \\ ${ }^{2}$ Department of Food Science and Technology, Jungwon University, Goesan 28024, Korea
}

\begin{abstract}
Ricinus communis, belongs to the family Euphorbiaceae, has been known as medicinal plants for treatment of inflammation, tumors, antidiabetic, hepatoprotective and laxative. Compared to many pharmacological studies, the effect of $\boldsymbol{R}$. communis extract on regulating adipogenesis as therapeutic drug for treating obesity has not been reported. $R$. communis extract (RCE) was investigated to determine its effects on the adipogenesis by monitoring the status of Wnt/ $\beta$-catenin signaling and factors involving the differentiation of adipocytes. The differentiation of 3T3-L1 cells monitored by Oil Red $O$ staining was inhibited in concentration dependent manner by RCE. The luciferase activity of HEK 293-TOP cells containing pTOPFlash with Tef4 response element-luciferase gene was increased approximately 2-folds by the treatment of RCE at concentrations of $100 \mu \mathrm{g} / \mathrm{mL}$ compared to the control. Activation of the Wnt/ $\beta$-catenin pathway by RCE was further confirmed by immunocytochemical analysis which shows an increment of nuclear localization of $\beta$-catenin. In addition, safety of RCE was verified through performing neural stem cell morphology assay. Among the identified flavonoids in RCE, isoquercitrin was the most abundant. Therefore, these results indicate that the adipocyte differentiation was significantly reduced by isoquercitrin in $R$. communis. In this study, RCE suppresses the adipogenesis of 3T3-L1 cells via the activation of Wnt/ $\beta$-catenin signaling.
\end{abstract}

Key words : Ricinus communis extract, 3T3-L1 cells, Wnt/ß-catenin pathway, adipogenesis

\section{Introduction}

The Wnt/ß-catenin signaling pathway mediates key cell-cell signaling events during embryogenesis as requirement for adult tissue maintenance, and is mandatory in adipogenesis (1). Wnt ligands are secreted proteins that act through autocrine and paracrine mechanisms to influence the differentiation of many different cell types (2). The Wnt/ $\beta$ -catenin pathway plays important physiological roles including embryonic development and cellular proliferation. Large number of studies have suggested that the Wnt/ $\beta$-catenin pathway plays a role in adipose cell communication and the inhibition of adipogenesis $(3,4)$. The understanding of molecular and cellular events regulating adipogenesis is

*Corresponding author. E-mail : hyun1006@jwu.ac.kr

Phone : 82-43-830-8616, Fax : 82-43-830-8679

Received 8 March 2017; Revised 12 April 2017; Accepted 10 May 2017.

Copyright (c) The Korean Society of Food Preservation. All rights reserved. crucial for designing rational therapies for prevention or treatment of obesity and metabolic syndromes (5).

Ricinus communis is a soft-wood small tree which is widespread throughout tropics and warm temperature regions of the world. The by-products this plant, such as leaf and root have been used for treatment of inflammation $(6,7)$. In addition, oils from $R$ communis have been reported to have potential antimicrobial, anticarcinogenic, and antioxidant activities $(8,9)$. However, compared to many pharmacological studies, the effect of $R$ communis extract on regulating adipogenesis as therapeutic drug for the treatment of obesity has not been reported. In this study, we investigated the effect of $R$ communis extract on inhibition of the adipocyte differentiation through activating the $\mathrm{Wnt} / \beta$-catenin signaling pathway.

\section{Materials and Methods}

\section{Preparation of $R$. communis extract}

$R$ communis (whole plant) extract was purchased from 
Plant Extract Bank (http://extract.pdrc.re.kr; Daejeon, Korea) The extract obtained from $30-40 \mathrm{~g}$ of crude sample was mixed with $200 \mathrm{~mL}$ of methanol using a solvent extraction equipment (ASE300 Accelerated Solvent Extractor, DIONEX Corporation, Sunnyvale, CA, USA) at $50^{\circ} \mathrm{C}$, and 1,500 psi for $20 \mathrm{~min}$ and dried (Modul spin 40, Biotron corporation, Alberta, Canada) at $40^{\circ} \mathrm{C}$ for $24 \mathrm{~h}$.

\section{Cell culture}

The 3T3-L1 preadipocytes (10) were cultured in Dulbecco's modified Eagle's medium (DMEM) with high glucose concentration, $110 \mathrm{mg}$ pyruvate/L supplemented with thermally inactivate $10 \%$ (v/v) calf serum (Gibco, Waltham, MA, USA), $100 \mu \mathrm{g} / \mathrm{mL}$ penicillin, and $100 \mu \mathrm{g} / \mathrm{mL}$ streptomycin in a $\mathrm{CO}_{2}$ incubator at $37^{\circ} \mathrm{C}$. To induce adipocyte differentiation, 3T3-L1 cells were cultured with DMEM plus $10 \%$ (v/v) heat inactivated fetal bovine serum (FBS) (Gibco) containing $520 \mu \mathrm{M}$ isobutylmethylxanthine, $1 \mu \mathrm{M}$ dexamethasone and $167 \mathrm{nM}$ insulin. After 2 days, the media was then changed, and $167 \mathrm{mM}$ of insulin in distilled water was added in a 1:1,000 dilution. On day 4, medium was replaced with DMEM containing $10 \%$ FBS, and changed with fresh identical medium every 2 days. To measure the anti- differentiation effects of each drug, 3T3-L1 preadipocytes were induced to differentiate in the presence of different concentrations of $R$. communis extract and $\mathrm{LiCl}$ (Lithum Chloride).

\section{Luciferase assay}

HEK 293-TOP cells $\left(3 \times 10^{4}\right)$ containing pTOPFlash with Tcf4 response element-luciferase gene were seeded into 96-well plates and incubated in DMEM medium with $10 \%$ FBS in a $\mathrm{CO}_{2}$ incubator at $37^{\circ} \mathrm{C}$ for 1 day. The cells were then treated with RCE $(1,10,100 \mu \mathrm{g} / \mathrm{mL})$ for $24 \mathrm{~h}$. Total cell lysates were extracted with $25 \mu \mathrm{L} \mathrm{1x}$ reporter lysis buffer (Promega, Madison, WI, USA) per each well and luciferase activities were measured by adding $25 \mu \mathrm{L}$ luciferin (USB, Cleveland, OH, USA) per each well using a Microplate Luminometer (BMG Labtech, Offenburg, Germany).

\section{Oil Red O staining}

Dye solution was prepared as follows: $150 \mathrm{mg}$ Oil Red $\mathrm{O}$ was dissolved in $30 \mathrm{~mL}$ of isopropanol. Then, the precipitate was removed by filtration and the supernatant was stored at room temperature after addition of $20 \mathrm{~mL}$ of distilled water. Adipocyte cell layers were washed with PBS, fixed with $4 \%$ paraformaldehyde in PBS for $15 \mathrm{~min}$ at room temperature, stained with the Oil Red $\mathrm{O}$ dye solution for $1 \mathrm{~h}$, and then washed with distilled water. Cells were checked by the bright-field optical microscope (Nikon TE-200U, Tokyo, Japan).

\section{Immunocytochemistry}

Cells were fixed with $4 \%$ (v/v) paraformaldehyde in PBS for $15 \mathrm{~min}$ at room temperature and washed with PBS. For permeabilization, cells were treated with $0.1 \%$ (v/v) Triton $\mathrm{X}-100$ for $15 \mathrm{~min}$ at room temperature. And, cells were blocked with $5 \%(\mathrm{v} / \mathrm{v})$ BSA and $1 \%(\mathrm{v} / \mathrm{v})$ normal goat serum in PBS for $30 \mathrm{~min}$ at room temperature and successively incubated with mouse anti- $\beta$-catenin antibody (BD transduction laboratory, Lexington, KY, USA, 1:100) overnight at $4{ }^{\circ} \mathrm{C}$. Cells were rinsed with PBS, incubated with Alexa Fluor 488-conjugated goat anti-mouse antibody (Molecular Probes, Eugene, OR, USA, 1:400) for $1 \mathrm{~h}$ at room temperature, counterstained with 4'-6- Diamidino-2-phenylindole (DAPI) (Boehringer Mannheim, Mannheim, Germany, 1:5,000), and examined under a confocal microscope, LSM510 META (Carl Zeiss, Gottingen, Germany).

\section{Primary rat neural stem cell culture}

Primary rat neural stem cells were isolated from the cerebral cortex of E14 Sprague-Dawley (SD) rats (KOATECH, Namyangju, Korea). The isolated cells were plated in dishes coated with $15 \mu \mathrm{g} / \mathrm{mL}$ poly-L-ornithine and $10 \mu \mathrm{g} / \mathrm{mL}$ fibronectin (Sigma-Aldrich, St. Louis, MI, USA), grown in $\mathrm{N}_{2}$ medium [DMEM:F12 (1:1) (Invitrogen) containing 100 $\mu \mathrm{M}$ putrescine, $30 \mathrm{nM}$ selenite, $20 \mathrm{nM}$ progesterone, 1.55 $\mathrm{mg} / \mathrm{mL} \mathrm{D}-(+)-g l u c o s e, 25 \mathrm{\mu g} / \mathrm{mL}$ insulin, $0.1 \mu \mathrm{g} / \mathrm{mL}$ apotransferrin (Sigma-Aldrich), $0.5 \mathrm{mM}$ Glutamax, $100 \mathrm{IU} / \mathrm{mL}$ penicillin, and $100 \mu \mathrm{g} / \mathrm{mL}$ streptomycin] containing $10 \mathrm{ng} / \mathrm{mL}$ bFGF (basic Fibroblast Growth Factor; Invitrogen, Carlsbad, CA, USA), or valproic acid (VPA) as an inducer of neural tube defects and incubated in $5 \%(\mathrm{v} / \mathrm{v}) \mathrm{CO}_{2}$ at $37^{\circ} \mathrm{C}$. To monitor toxicity of RCE, the cells were plated at $2 \times 10^{5}$ cells per each well in a 6-well plate and treated with $5 \mu \mathrm{g} / \mathrm{mL}$ RCE for $48 \mathrm{~h}$. The animal experimental procedures were approved by the committee for the Care and Use of Laboratory Animals, Yonsei University College of Medicine and were performed in accordance with the Committee's Guidelines and Regulations for Animal Care (IRB No. 09-013).

\section{HPLC analysis}

The HPLC analysis was carried out in Agilent 1260 HPLC-DAD system as following conditions: injection volume, (10 $\mathrm{LL}$ ); Capcell pak C18, UG, 5um, column 4.6×250 
mm, (Agilent Technologies Inc, Santa Clara, CA, USA), column temperature at $35^{\circ} \mathrm{C}$, mobile phase $\mathrm{A}$ being acetonitrile/acetic acid/water $(3 / 0.5 / 96.5, \mathrm{v} / \mathrm{v} / \mathrm{v})$ and mobile phase B acetonitrile /acetic acid/water (50/0.5/49.5,v/v/v), linear gradient elution from $72.5 \% \mathrm{~A} / 27.5 \% \mathrm{~B}(\mathrm{v} / \mathrm{v})$ to $65 \%$ $\mathrm{A} / 35 \% \mathrm{~B}(\mathrm{v} / \mathrm{v})$ during 0-10 min, from $65 \% \mathrm{~A} / 35 \% \mathrm{~B}(\mathrm{v} / \mathrm{v})$ to $20 \% \mathrm{~A} / 80 \% \mathrm{~B}(\mathrm{v} / \mathrm{v})$ during 10-35 min, from $20 \% \mathrm{~A} / 80 \%$ $\mathrm{B}(\mathrm{v} / \mathrm{v})$ to $0 \% \mathrm{~A} / 100 \% \mathrm{~B}(\mathrm{v} / \mathrm{v})$ during $35-40 \mathrm{~min}$; mobile phase flow rate was $1 \mathrm{~mL} / \mathrm{min}$. The samples were monitored at $360 \mathrm{~nm}$. Flavonoids and their derivatives in the tested sample were determined by comparing the retention times and peak areas with those of authentic reference compounds (Fig. 5). The identified compounds were confirmed by internal standard (11).

\section{Statistics}

All data are presented as the mean \pm SD. Comparisons between multiple groups were performed with one-way ANOVA (Analysis of Variance) with Bonferroni's test. The p-value of less than 0.05 was considered significant.

\section{Results and Discussion}

RCE inhibits the adipocyte differentiation of 3T3-L1 cells

The differentiation of cells monitored by Oil Red O staining

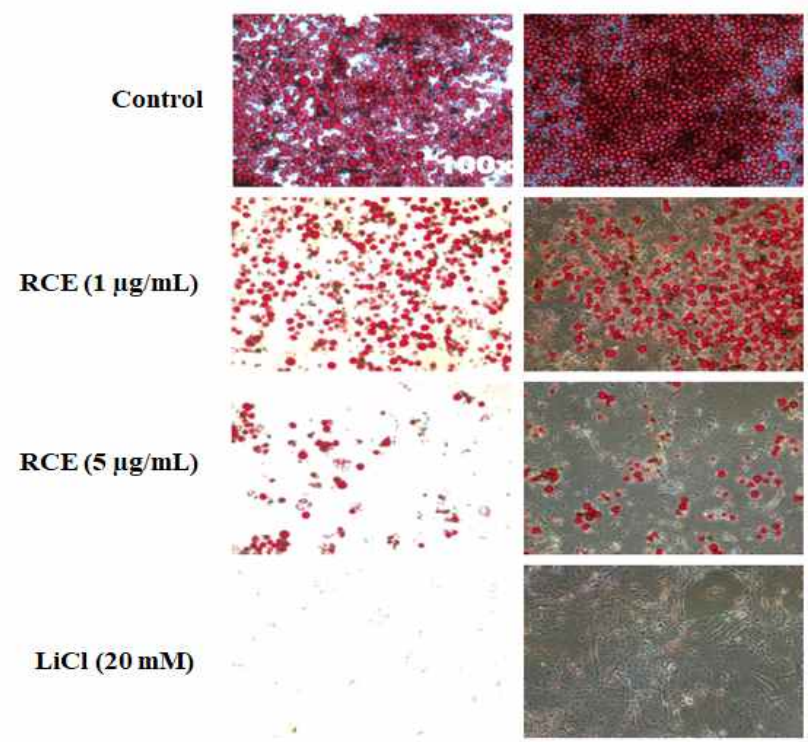

Fig. 1. Effect of $R$. communis extract (RCE) on the adipocyte differentiation of 3T3-L1 preadipocyte cells.

3T3-L1 cells were inhibited to differentiation for 7 days with or without $20 \mathrm{mM} \mathrm{LiCl}$. Intracellular lipids of 3T2-L1 cells were visualized by Oil Red O staining as described in the Materials and methods. Original magnification: $\times 100$. was totally abolished by the treatment of $20 \mathrm{mM}$ of $\mathrm{LiCl}$, and the GSK3 $\beta$ inhibitor activated the Wnt/ $\beta$-catenin signaling. RCE subsequently inhibited the adipocyte differentiation of 3T3-L1 cells in concentration-dependent manner (Fig. 1). These results suggest that RCE inhibited the differentiation of 3T3-L1 cells which indicated the role of the Wnt/ $\beta$-catenin activator in the adipocyte differentiation.

RCE activates the $\mathrm{Wnt} / \beta$-catenin signaling pathway

The luciferase activity of HEK 293-TOP cells specifically increased approximately 2-folds by the treatment of RCE at concentrations of $100 \mu \mathrm{g} / \mathrm{mL}$, as compared to the non-treated control (Fig. 2). Activation of the Wnt/ $\beta$-catenin pathway by RCE was further confirmed by immunocytochemical analysis which shows an increment of nuclear localization of $\beta$-catenin (Fig. 3). Here, $\beta$-catenin similarly increased and nuclear localized as shown by the treatment of $\mathrm{LiCl}$, which was used as the positive control. These results indicated that the activation of the Wnt/ $\beta$-catenin signaling by RCE was specific (12). The $\mathrm{Wnt} / \beta$-catenin signaling plays a role in the suppression of the differentiation of pre-adipocyte cells during the adipocyte differentiation of 3T3-L1 cells. Therefore, the Wnt/ $\beta$-catenin pathway could be an attractive target for monitoring development adipocytes differentiation (13).

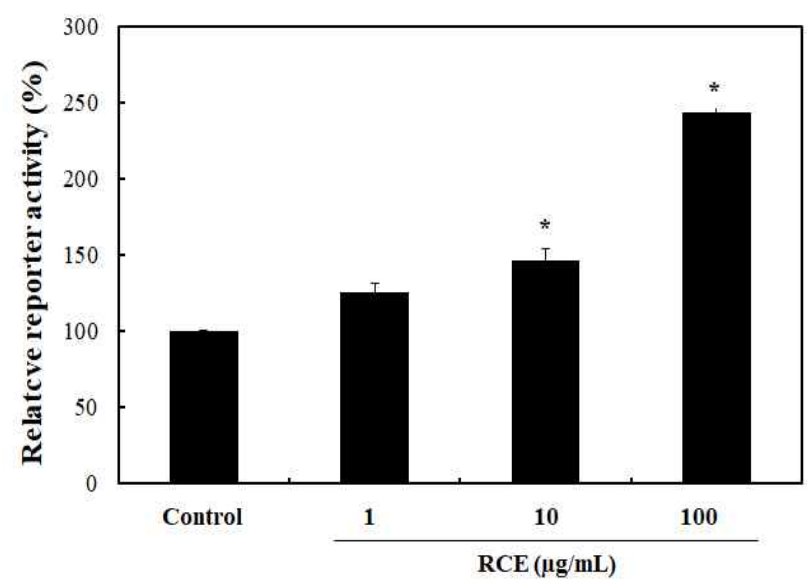

Fig. 2. Effect of RCE on the Wnt/B-catenin pathway reporter activity.

HEK293 cells containing pTOPFlash reporter gene in its chromosome were cultured and treated with different RCE at 1,10 or $100 \mu \mathrm{g} / \mathrm{mL}$ concentration, and cellular extract was prepared after $24 \mathrm{~h}$ as described in the Materials and methods. Values are presented as mean \pm SD. Differences were considered statistically significant when ${ }^{*} p<0.05$.

\section{Effect of RCE on toxicity in rat neuronal stem cells}

Neural stem cells have been used to screen compound 


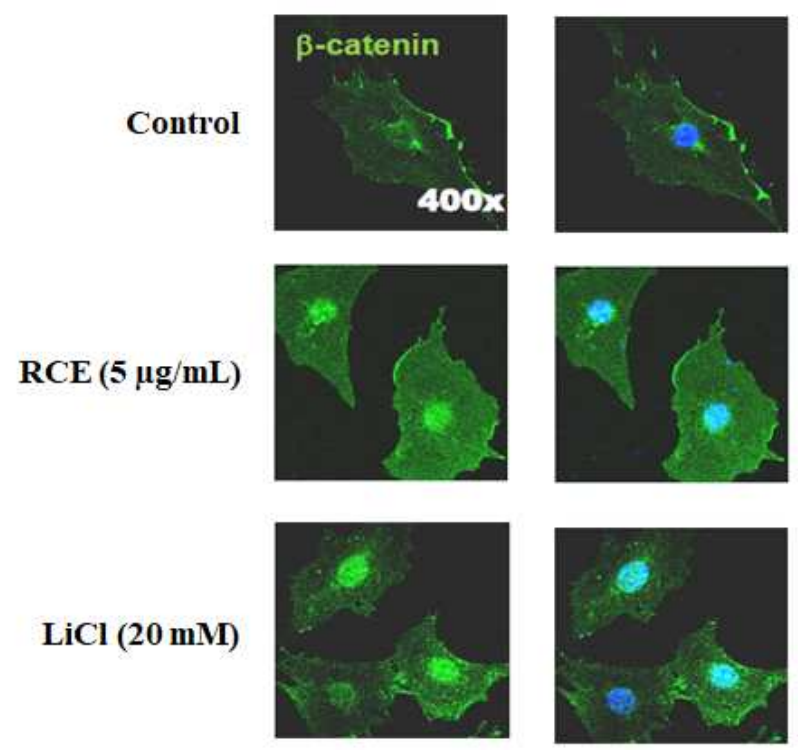

Fig. 3. Effect of RCE on activation of the Wnt/B-catenin signaling pathway.

3T3-L1 cells were stimulated with $20 \mathrm{mM} \mathrm{LiCl}$, or $5 \mu \mathrm{g} / \mathrm{mL}$ RCE. Cells were subjected to immunocytochemical analysis with the anti- $\beta$-catenin antibody. Nuclei were counter stained by DAPI. Original magnification: $\times 400$.

-bFGF

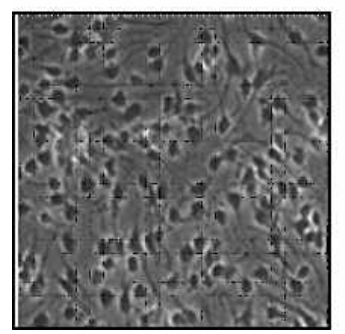

+bFGF

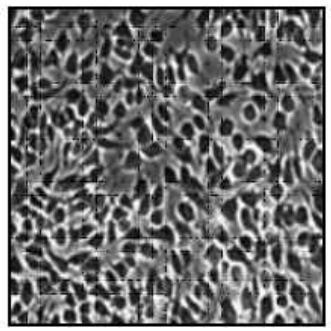

VPA $1 \mathrm{mM}$

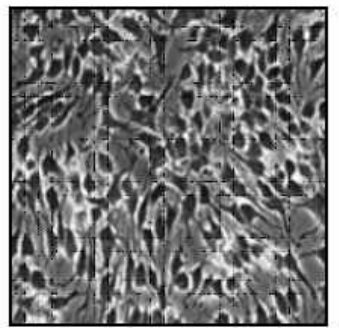

RCE $(5 \mu \mathrm{g} / \mathrm{mL})$

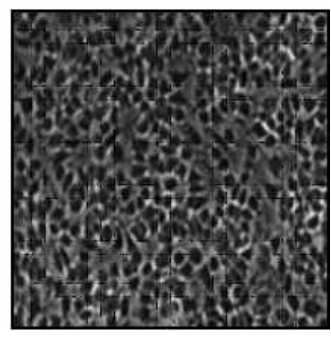

Fig. 4. Morphology of rat neuronal stem cells after treatment of RCE.

Bright field microscopy images of rat neuronal stem cells. The cells were treated with $5 \mu \mathrm{g} / \mathrm{mL}$ RCE for $48 \mathrm{~h}$ in the presence of $10 \mathrm{ng} / \mathrm{mL}$ bFGF.

toxicity (14). To monitor toxicity of RCE, we examined the effect of RCE in rat neural stem cells. The cells were treated with $5 \mathrm{\mu g} / \mathrm{mL}$ RCE for $48 \mathrm{~h}$ in the presence of $10 \mathrm{ng} / \mathrm{mL}$ bFGF. Cytotoxicity of RCE was not detected in the rat neural stem cells (Fig. 4).

\section{HPLC analysis}

Several peaks were monitored in the HPLC profile of RCE (Fig. 5). One peak was qualitatively identified based on retention times of 15 HPLC reference compounds used, and the other compounds were not identified owing to lack of authentic references. Among the identified flavonoids, isoquercitrin was the most abundant. There were several reports on the mechanism for the anti-obesity effects of flavonoids, such as isorhamnetin and quercetin (15), and reporter activity (12). Therefore, these results indicated that the adipocyte differentiation was critically reduced by isoquercitrin in $R$ communis. This study investigated whether natural plant extract may regulate the $\mathrm{Wnt} / \beta$ catenin signaling and adipogenesis. $R$ communis, a soft wood small tree found throughout tropics and warm temperature regions of the world, was identified as an activator of the $\mathrm{Wnt} / \beta$ catenin signaling. The RCE subsequently inhibited the adipocyte differentiation of 3T3 L1 cells. In this regard, RCE may be an appropriate material for the treatment of obesity.

\section{Acknowledgments}

This research was supported by Basic Science Research 
Program through the National Research Foundation of Korea (NRF) founded by the Ministry of Education (2014R1A1A2057651).

\section{References}

1. Liu J, Farmer SR (2004) Regulating the balance between peroxisome proliferator-activated receptor $V$ and $\beta$ -catenin signaling during adipogenesis. A glycogen synthase kinase $3 \beta$ phosphorylation-defective mutant of $\beta$-catenin inhibits expression of a subset of adipogenic genes. J Biol Chem, 279, 45020-45027

2. Logan CY, Nusse R (2004) The Wnt signaling pathway in development and disease. Annu Rev Cell Dev Biol, 20, 781-810

3. Ross SE, Hemati N, Longo KA, Bennett CN, Lucas PC, Erickson RL, MacDougald OA (2000) Inhibition of adipogenesis by Wnt signaling. Science, 289, 950-953

4. Kennell JA, MacDougald OA (2005) Wnt signaling inhibits adipogenesis through $\beta$-catenin-dependent and -independent mechanisms. J Biol Chem, 280, 2400424010

5. Fruhbeck G, Gomez-Ambrosi J, Muruzabal FJ, Burrell MA (2001) The adipocyte: a model for integration of endocrine and metabolic signaling in energy metabolism regulation. Am J Physiol Endocrinol Metab, 280, 827-847

6. Capasso F, Mascolo N, Izzo AA, Gaginella TS (1994) Dissociation of castor oil-induced diarrhoea and intestinal mucosal injury in rat: effect of NG-nitro-L-arginine methyl ester. Br J Pharmacol, 113, 1127-1130

7. Shokeen P, Anand P, Murali YK, Tandon V (2008) Antidiabetic activity of $50 \%$ ethanolic extract of Ricinus communis and its purified fractions. Food Chem Toxicol, 46, 3458-3466

8. Kadri A, Gharsallah N, Damak M, Gdoura R (2011) Chemical composition and in vitro antioxidant properties of essential oil of Ricinus communis L.. J Med Plants Res, 5, 1466-1470

9. Naz R, Bano A (2012) Antimicrobial potential of Ricinus communis leaf extracts in different solvents against pathogenic bacterial and fungal strains. Asian Pac J Trop Biomed, 2, 944-947

10. Zhang M, Ikeda K, Xu JW, Yamori Y, Gao XM, Zhang
BL (2009) Genistein suppresses adipogenesis of 3T3-L1 cells via multiple signal pathways. Phytother Res, 23, 713-718

11. Uesawa Y, Mohri K (2005) Comprehensive determination of furanocoumarin derivatives in citrus juice by high performance liquid chromatography. J Pharm Soc Jpn, $125,875-879$

12. Lee SH, Kim B, Oh MJ, Yoon J, Kim HY, Lee KJ, Lee JD, Choi KY (2011) Persicaria hydropiper (L.) spach and its flavonoid components, isoquercitrin and isorhamnetin, activate the $\mathrm{Wnt} / \beta$-catenin pathway and inhibit adipocyte differentiation of 3T3-L1 cells. Phytother Res, 25, 1629-1635

13. Christodoulides C, Lagathu C, Sethi JK, Vidal-Puig A (2009) Adipogenesis and WNT signalling. Trends Endocrinol Metab, 20, 16-24

14. Meli L, Barbosa HSC, Hickey AM, Gasimli L, Nierode G, Diogo MM, Linhardt RJ, Cabral JMS, Dordick JS (2014) Three dimensional cellular microarray platform for human neural stem cell differentiation and toxicology. Stem Cell Res, 13, 36-47

15. Ahn JY, Lee HJ, Kim SN, Park JH, Ha TY (2008) The anti-obesity effect of quercetin is mediated by the AMPK and MAPK signaling pathways. Biochem Biophys Res Commun, 373, 545-549

16. Rayalam S, Yang JY, Ambati S, Della-Fera MA, Baile CA (2008) Resveratrol induces apoptosis and inhibits adipogenesis in 3T3-L1 adipocytes. Phytother Res, 22, 1367-1371

17. Ahn JY, Lee HJ, Kim SN, Ha TY (2010) Curcumininduced suppression of adipogenic differentiation is accompanied by activation of $\mathrm{Wnt} / \beta$-catenin signaling. Am J Physiol Cell Physiol, 298, 1510-1516

18. Kim MH, Park JS, Seo MS, Jung JW, Lee YS, Kang KS (2010) Genistein and daidzein repress adipogenic differentiation of human adipose tissue-derived mesenchymal stem cells via Wnt/ $\beta$-catenin signalling or lipolysis. Cell Prolif, 43, 594-605

19. Lee H, Kang R, Hahn Y, Yang Y, Kim SS, Cho SH, Chung SI, Yoon Y (2009) Antiobesity effect of baicalin involves the modulations of proadipogenic and antiadipogenic regulators of the adipogenesis pathway. Phytother Res, 23, 1615-1623 